\title{
Awards and Grants
}

\section{Eight Best Abstracts}

The authors of the abstracts below will receive a diploma.

SO014 THE Pkhd1 COMPLEX TRANSCRIPTIONAL MECHANISM GIVES RISE TO ALTERNATIVE TRANSCRIPTS WITH PRESERVED OPEN READING FRAME, A PATTERN DISRUPTED BY A FRAMESHIFT MUTATION.

Luiz Onuchic, Sao Paulo, Brazil

SO016 URINARY MIDKINE IS A SENSITIVE BIOMARKER OF ACUTE TUBULAR NECROSIS IN HUMAN Hiroki Hayashi, Nagoya, Japan

SO045 HEREDITARY FIBRINOGEN A alpha ALPHA-CHAIN AMYLOIDOSIS: PHENOTYPIC CHARACTERIZATION AND OUTCOME OF COMBINED LIVER AND KIDNEY TRANSPLANTATION Arie J. Stangou, London, UK

SO055 PDGF-C ACCELERATES GLOMERULAR CAPILLARY REPAIR IN EXPERIMENTAL GLOMERULONEPHRITIS

Peter Boor, Bratislava, Slovakia

MO005 CALCIFICATION OUTCOME IN RENAL DISEASE (CORD) STUDY - TWO-YEAR PROGRESSION AND PROGNOSTIC VALUE OF ABDOMINAL AORTIC CALCIFICATION IN DIALYSIS AND AFTER RENAL TRANSPLANTATION

Eero Honkanen, Helsinki, Finland

MP112 INHIBITORY EFFECT OF RECEPTOR-ASSOCIATED PROTEIN ON MYELOMA LIGHT CHAIN INDUCED CYTOKINE RELEASE IN CULTURED HUMAN PROXIMAL TUBULAR CELLS Sule Sengul, Ankara, Turkey

MP356 LESS THROMBOGENIC MICROPATTERNED POLYMER MODIFIED SURFACE IMPROVES TEMPORARY HEMODIALYSIS CATHETER SURVIVAL IN PATIENTS WITH END-STAGE RENAL DISEASE

Pascal Meier, Sion, Switzerland

MP387 CHANGES BETWEEN 1999 AND 2005 IN THE RISK OF DEATH WITH HIGH OR LOW HAEMOGLOBINS IN UK HAEMODIALYSIS PATIENTS; DATA FROM 32,500 PATIENT YEARS OBSERVATION

David Ansell, Bristol, UK

\section{Eleven Best Abstracts presented by young Authors}

The authors of the abstracts below will receive a cheque of $€ 1000$, free congress registration and a diploma.

SO011 FUNCTIONAL AND MOLECULAR CHARACTERIZATION OF ADULT RENAL RESIDENT STEM CELLS OF AUTOSOMAL DOMINANT POLYCYSTIC KIDNEY DISEASE PATIENTS

Benedetta Bussolati, Torino, Italy

SO016 URINARY MIDKINE IS A SENSITIVE BIOMARKER OF ACUTE TUBULAR NECROSIS IN HUMAN Hiroki Hayashi, Nagoya, Japan

SO047 PERITUBULAR CAPILLARY AND VASCULAR MACROPHAGE INFILTRATION CORRELATES WITH MICRROVASCULAR DESTRUCTION AND WORSENS STEORID RESPONSE AND RENAL ALLOGRAFT OUTCOMES FOLLOWING C4D NEGATIVE ACUTE REJECTION EPISODES

Binnaz Handan Ozdemir, Ankara, Turkey

SO050 WARFARIN-INDUCED CALCIFICATION IN MICE - A NOVEL TOOL TO INVESTIGATE INTERACTIONS OF CALCIFICATION INHIBITORS

Thilo Krueger, Aachen, Germany 
SO051 VASCULAR CALCIFICATION IMPLIES DIFFRENTIAL GENE EXPRESSION PROFILE WITH DEREGULATION OF THE SFRPs FAMILY

Pablo Roman-Garcia, Oviedo, Spain

SO055 PDGF-C ACCELERATES GLOMERULAR CAPILLARY REPAIR IN EXPERIMENTAL GLOMERULONEPHRITIS

Peter Boor, Bratislava, Slovakia

MO034 INDUCIBLE RAT NEPHRIN TRANSGENE EXPRESSION IN PODOCYTES RESCUES NEPHRIN DEFICIENT MICE FROM PERINATAL DEATH

Juuso Juhila, Dublin, Ireland

MO039 CATION TRANSPORT ACTIVITY IN FUNCTIONAL ANION EXCHANGERS; A NOVEL PROPERTY OF DISTAL RENAL TUBULAR ACIDOSIS (dRTA) ASSOCIATED ANION EXCHANGER 1 (AE1, BAND 3) MUTANTS

Stephen Walsh, London, UK

MP073 RENAL FUNCTION DURING THE FIRST WEEKS FOLLOWING LUNG TRANSPLANTATION Mads Hornum, Copenhagen, Denmark

MP460 NON-INVASIVE DETECTION OF ACUTE ALLOGRAFT REJECTION AFTER RAT RENAL TRANSPLANTATION BY FLUOR-DESOXY-GLUCOSE-SMALL-ANIMAL-POSITRON EMISSION TOMOGRAPHY

Stefan Reuter, Muenster, Germany

TO016 SERUM CARDIAC TROPONIN-T CONCENTRATIONS ARE ASSOCIATED WITH OUTCOME IN PATIENTS WITH MYOCARDIAL STUNNING

James Burton, Derby, UK

\section{Best Abstracts presented by young Authors}

The authors of the abstracts below will receive a cheque of $€ 500$, free congress registration and a certificate.

SO001 PHYSIOLOGICAL AND MOLECULAR MECHANISMS UNDERLYING THE FUNCTIONAL ADAPTATION OF ADULT-SIZED KIDNEYS TRANSPLANTED INTO PAEDIATRIC RECIPIENTS

Maarten Naesens, Leuven, Belgium

SO002 CYCLOSPORIN INDUCES EPITHELIAL TO MESENCHYMAL TRANSITION IN RENAL GRAFTS Alexandre Hertig, Paris, France

SO006 OUTCOME OF ANCA ASSOCIATED VASCULITIS - LONG-TERM FOLLOW UP OF FOUR RANDOMISED CONTROLLED TRIALS

Oliver Flossmann, Cambridge, UK

SO009 CHANCES OF DIALYSIS INDEPENDENCE AFTER PLASMAEXCHANGE IN RENAL ANCA ASSOCIATED VASCULITIS

Cristina Marcuccio, Torino, Italy

SO013 EVEROLIMUS PULSE TREATMENT HALTS POLYCYSTIC KIDNEY DISEASE PROGRESSION LONG-LASTING IN Cy/+ RAT

Ming Wu, Zurich, Switzerland

SO015 DISEASES LINKED TO TCF2/HNF-1B GENE ANOMALIES: FROM FOETUS TO ADULT

Stephane Decramer, Toulouse, France

SO018 SHIGA TOXINS BOUND TO POLYMORPHONUCLEAR LEUKOCYTES (StXs-PMN): CLINICAL OBSERVATIONS IN CHILDREN WITH HEMOLYTIC UREMIC SYNDROME (HUS)

Laura Fuiano, Naples, Italy

SO022 DECREASED ENDOTHELIAL PROGENITOR CELLS IN TYPE 2 DIABETIC PATIENTS WITH MICROALBUMINURIA OR MACROALBUMINURIA

Gerit-Holger Schernthaner, Vienna, Austria

SO023 OVERT TYPE 1 DIABETIC NEPHROPATHY: EFFECT OF ADD2 AND ACE POLYMORPHYSMS ON PROGRESSION TOWARDS END STAGE RENAL DISEASE

Giovanna Bonavida, Milano, Italy 
SO025 INHIBITION OF mTOR ARREST HIGH GLUCOSEINDUCING GLOMERULAR MESANGIAL CELLS SENESCENCE BY UPREGULATION OF SIRT1

Guangyan Cai, Beijing, China

SO027 RHOA AND RHOC DIFFERENTIALLY REGULATE THE EXPRESSION OF E-CADHERIN AND alpha-SMOOTH MUSCLE ACTIN DURING EPITHELIAL TO MESENCHYMAL TRANSITION

Nicol Hutchison, London, UK

SO034 THE INFLUENCE OF CHRONIC KIDNEY DISEASE ON HIP-FRACTURE RELATED MORTALITY IN OLDER PEOPLE IN THE UNITED KINGDOM

Dorothea Nitsch, London, UK

SO035 INFLUENCE OF DIET QUALITY AND DIET PATTERNS ON ALBUMINURIA IN WOMEN Julie Lin, Boston, USA

SO036 PROGNOSTIC ASSOCIATION OF SERUM PHOSPHATE IN PATIENTS WITH CHRONIC KIDNEY DISEASE NOT ON DIALYSIS

Helen Eddington, Salford, UK

SO044 TOLERANCE-INDUCING ENZYME INDOLEAMINE 2,3-DIOXYGENASE IS EXPRESSED IN PATIENTS AFTER COMBINED AUXILIARY LIVER AND KDINEY TRANSPLANTATION

Madeleine Ingelsten, Goteborg, Sweden

SO052 THE IMPACT OF CORONARY ARTERY CALCIFICATION ON MORTALITY IN HEMODIALYSIS PATIENTS

Gulay Asci, Izmir, Turkey

SO056 IMATINIB (IMB) AND PLATELET-DERIVED GROWTH FACTOR RECEPTOR (PDGFR) beta SPECIFIC INHIBITION ATTENUATE CRYOGLOBULINEMIC MEMBRANOPROLIFERATIVE

GLOMERULONEPHRITIS (MPGN) IN MICE

Masayuki Iyoda, Tokyo, Japan

SO057 DYSREGULATION OF NFkappaB IN DISEASES: ROLE OF CMIP

Virginie Ory, Creteil, France

SO058 ACTIVATION OF TOLL-LIKE RECEPTORS EPRESSED BY PODOCYTES LEADS TO INDUCTION OF CC AND CXC CHEMOKINES

M.C. Banas, Regensburg, Germany

SP049bis GENETICALLY DETERMINED LOW NEPHRON NUMBER IS NOT ASSOCIATED WITH ALTERATIONS IN POSTGLOMERULAR STRUCTURE AS A POTENTIAL EXPLANATION FOR SUBSEQUENT DEVELOPMENT OF HYPERTENSION

Kerstin Benz, Erlangen, Germany

SP051 PYRROLIDINE DITHIOCARBAMATE ATTENUATES LIPOPOLYSACCHARIDE-INDUCED ACUTE RENAL FAILURE IN MICE

Klaus Hocherl, Regensburg, Germany

SP055 VASCULAR CALCIFICATION IS PREVENTED BY 2\% LANTHANUM CARBONATE TREATMENT IN RATS WITH ADENINE-INDUCED CHRONIC RENAL FAILURE

Veerle Persy, Antwerp, Belgium

SP081 APROTININ AS A RISK FACTOR FOR RENAL REPLACEMENT THERAPY AFTER LIVER TRANSPLANTATION

Roberto Narciso, Sao Paulo, Brazil

SP126 ELEVATED PLASMA URIC ACID LEVELS INCREASE THE RISK FOR NEW-ONSET KIDNEY DISEASE Rudolf Paul Obermayr, Wien, Austria

SP138 INTRODUCTION OF AN INTERNATIONAL INTERNET-BASED REGISTRY FOR CALCIFIC UREMIC ARTERIOLOPATHY (CUA)

Vincent Brandenburg, Aachen, Germany

SP151 SELECTIVE PDE5 INHIBITION AMELIORATES PROGRESSION OF DIABETIC NEPHROPATHY IN THE RAT

Gabor Kokeny, Budapest, Hungary 
SP157 PARATHYROID HORMONE-RELATED PROTEIN REGULATES THE ACTIVITY OF CDK2/CYCLIN E AND p27Kip1 ON HUMAN MESANGIAL CELL. ROLE IN DIABETIC NEPHROPATHY

Montserrat Romero, Alcala de Henares, Spain

SP200 MYCOPHENOLATE MOFETIL AS RESCUE THERAPY IN PATIENTS WITH LUPUS NEPHRITIS WHO HAVE FAILED TO RESPOND TO CONVENTIONAL TREATMENT WITH INTRAVENOUS CYCLOPHOSPHAMIDE

Yl Thye, Kuala Lumpur, Malaysia

SP219 A NOVEL HYPERTENSIVE TRANSGENIC MOUSE TO STUDY REGULATION OF GENES INVOLVED IN CHRONIC RENAL DISEASE

Anne-Cecile Huby, Paris, France

SP226 INCREASED PRODUCTION OF VEGF BY SENESCENT HUMAN PERITONEAL MESOTHELIAL CELLS: THE ROLE OF OXIDATIVE STRESS

Krzysztof Ksiazek, Poznan, Poland

SP227 A NOVEL ROLE FOR CCN3 IN THE KIDNEY: INDUCTION OF GLOMERULAR ANGIOGENESIS Claudia R.C. van Roeyen, Aachen, Germany

SP299 ORAL CHARCOAL ADSORBENT (AST-120) PREVENTS THE PROGRESSION OF CARDIAC DAMAGE IN CHRONIC KIDNEY DISEASE BY SUPPRESSING OXIDATIVE STRESS

Hideki Fujii, Kobe, Japan

SP362 PROTECTIVE EFFECTS OF EPOETIN DELTA ON THE KIDNEY IN A MODEL OF CHRONIC RENAL FAILURE

Anja Verhulst, Antwerp, Belgium

SP414 THE IMPORTANCE OF GPI-ANCHORED PROTEINS IN THE ETHIOPATHOGENESIS OF THE MALNUTRITION, INFLAMMATION AND ATHEROSCLEROSIS SYNDROME IN CHRONIC RENAL PATIENTS UNDERGOING HEMODIALYSIS

Dubravka Mihaljevic, Osijek, Croatia

SP452 OBESITY IS A RISK FACTOR FOR DECLINE OF RENAL FUNCTION AFTER THE START OF DIALYSIS Christiane Drechsler, Leiden, Netherlands

SP453 C-REACTIVE PROTEIN (CRP) AND MORTALITY IN HEMODIALYSIS PATIENTS: THE DIALYSIS OUTCOMES AND PRACTICE PATTERNS STUDY (DOPPS)

Takehiko Kawaguchi, Kyoto, Japan

SP459 RISK FACTORS FOR SEVERE BACTERIAL INFECTIONS IN PATIENTS STARTING DIALYSIS THERAPY Josefin Ullberg, Stockholm, Sweden

SP466 PATIENTS' BELIEFS ABOUT THEIR END STAGE RENAL DISEASE ARE ASSOCIATED WITH MORTALITY RATES

S. van Dijk, Leiden, Netherlands

SP472 IN SEARCH OF THE MOST EFFICIENT GRAFT INJURY MARKER: NGAL AND IL-18 ASSESSMENT AGAINST ESTABLISHED MARKERS IN EARLY POSTTRANSPLANTATION PERIOD

Malgorzata Zynek-Litwin, Wroclaw, Poland

SP478 ASSOCIATION OF INFLAMMATORY CYTOKINE POLYMORPHISMS WITH CARDIOVASCULAR DISEASE AFTER RENAL TRANSPLANT

Maria Cappuccilli, Bologna, Italy

SP482 PATIENTS WITH DIABETES HAVE WORSE PATIENT SURVIVAL BUT NOT NECESSARILY GRAFT SURVIVAL AFTER KIDNEY TRANSPLANTATION

Laura J. Kyllonen, Helsinki, Finland

SP485 VALIDATION OF THE FRIEDEWALD'S FORMULA FOR THE DETERMINATION OF LOW DENSITY LIPOPROTEIN CHOLESTEROL IN RENAL TRANSPLANT RECIPIENTS

Mustafa Balal, Adana, Turkey

SP501 ASSOCIATION OF VITAMIN D LEVELS WITH METABOLIC SYNDROME AND INSULIN RESISTANCE IN RENAL TRANSPLANT RECIPIENTS

Serkan Koc, Ankara, Turkey 
SP508 MYCOPHENOLIC ACID TROUGH LEVELS AND THEIR VARIABILITY IN STABLE KIDNEY TRANSPLANT PATIENTS

J Martins, Madrid, Spain

MO001 SUCCESSFUL INDUCTION OF TARGET GENES IN PARATHYROID CELL BY DIRECT INJECTION TECHNIQUE

Kazuhiro Shiizaki, Shimotsuke, Japan

MO004 25-HYDROXYVITAMIN D3 LEVELS AND CARDIOVASCULAR RISK MARKERS IN HAEMODIALYSIS PATIENTS

Patricia Matias, Vila Franca de Xira, Portugal

MO011 COMPARISON OF EIGHT-HOUR AND FOUR-HOUR THRICE WEEKLY HEMODIALYSIS

Soner Duman, Bornova/Izmir, Turkey

MO013 THE EFFECTS OF AN EXPERIMENTAL PERITONEAL DIALYSIS SOLUTION ON THE PERITONEUM IN A URAEMIC RAT MODEL

Marijke de Graaff, Amsterdam, Netherlands

MO021 SCREENING OF A KIDNEY cDNA LIBRARY FOR THE IDENTIFICATION OF AUTOIMMUNE PROTEINS FROM SERUM OF MEMBRANOUS NEPHROPATHY PATIENTS

Fabrizio Cavazzini, Modena, Italy

MO022 LOCAL C1q PRODUCTION BY ANTIGEN PRESENTING CELLS LEADS TO COMPLEMENT

ACTIVATION IN LUPUS NEPHRITIS

Nicoletta Fiore, Bari, Italy

MO024 APOPTOSIS IN PERIPHERAL BLOOD AND INFLAMMATION MARKERS IN PATIENTS WITH CHRONIC KIDNEY DISEASE (CKD)

Elli Koliousi, Ioannina, Greece

MO033 CONGENITAL ANOMALIES OF THE KIDNEY AND URINARY TRACT: EVALUATION OF THE LONG TERM OUTCOME BASED ON A SINGLE CENTRE EXPERIENCE

D. Somenzi, Parma, Italy

MO040 AQP2 EXPRESSION AND WATER ABSORPTION INCREASED BY CARBAMAZEPINE IN NORMAL RATS IMCD

Ana C. de Braganca, Sao Paulo, Brazil

MO047 IMPACT OF DIETARY SALT INTAKE ON PERITONEAL MEMBRANE TRANSPORT AND STRUCTURE IN RATS

Anneleen Pletinck, Ghent, Belgium

MO056 ACHIEVEMENT OF RECOMMENDED BLOOD PRESSURE GOALS IN CHRONIC KIDNEY DISEASE IMPROVES ARTERIAL STIFFNESS

Yin Ping Liew, Cleveland, USA

MP003 THE AQUARETIC AGENT SATAVAPTAN (SR121463) EXERTS AN ANTI-PROLIFERATIVE EFFECT ON RENAL CANCER: ROLE OF VASOPRESSIN RECEPTOR-2 (V2r)

Davide Bolignano, Messina, Italy

MP015 INHIBITION OF THE ACIDOSIS-SENSING L-GLN TRANSPORTER SNAT2 IMPAIRS PROLIFERATION OF LBRM-TG6 T-LYMPHOCYTES

George Kosmadakis, Leicester, UK

MP021 POLYMORPHISM IN THE TETRAHYDROFOLATE REDUCTASE GENE (MTHFR) IN THE NORMAL INDIAN POPULATION and IN PATIENTS OF END STAGE RENAL DISEASE ON MAINTAINENCE DIALYSIS

Debabrata Mukherjee, Jalandhar Cantt, India

MP050 PROTECTIVE ROLE OF ERDOSTEINE ON RADIOCONTRAST NEPHROPATHY IN RATS

Faruk Turgut, Ankara, Turkey

MP074 CATECHOL-O-METHYLTRANSFERASE (COMT) LL GENOTYPE PREDISPOSES FOR ACUTE RENAL FAILURE IN CARDIAC SURGERY PATIENTS

Anja Haase-Fielitz, Berlin, Germany 
MP110 SIMPLE CYSTATIN C FORMULA COMPARED TO SERUM CREATININE-BASED EQUATIONS FOR ESTIMATION OF GLOMERULAR FILTRATION RATE IN PATIENTS WITH DIABETES MELLITUS TYPE 2 AND CHRONIC KIDNEY DISEASE

Sebastjan Bevc, Maribor, Slovenia

MP113 FACTORS AFFECTING PROGRESSION OF ARTERIAL STIFFNESS IN CHRONIC KIDNEY DISEASE: AN OUTPATIENTS BASED STUDY

Smeeta Sinha, Salford, UK

MP128 HIGH PREVALENCE OF CKD IN THE MIDDLE-AGED UK POPULATION: THE SCOTTISH HEART HEALTH STUDY AND THE BRITISH REGIONAL HEART STUDY

Keith McCullough, Aberdeen, UK

MP131 IS CALIBRE A NEW INSIGHT IN RENAL ARTERY STENOSIS?

Luca Zanoli, Catania, Italy

MP214 THROMBOMODULIN, VON WILLEBRAND FACTOR AND PLASMINOGEN ACTIVATOR INHIBITOR 1 AS MARKERS OF ENDOTHELIAL INJURY IN NEPHROTIC CHILDREN

Marcin Tkaczyk, Lodz, Poland

MP236 TRANSFERRIN RECEPTOR ENGAGEMENT BY POLYMERIC IgA1 INDUCES CELL PROLIFERATION AND CYTOKINE SECRETION THROUGH MAPK AND PI3K/ Akt/mTOR PATHWAYS IN HUMAN MESANGIAL CELLS

Ivan C. Moura, Paris, France

MP260 INFLUENCE OF USING A LOW-CALCIUM DIALYSATE ON ACHIEVING THE TARGET PARAMETERS OF CALCIUM-PHOSPHORUS METABOLISM IN A POPULATION OF HEMODIALYSIS PATIENTS

Adrian Dorin Zugravu, Bucharest, Romania

MP273 IS DIALYSATE SOLUBLE CD44 INVOLVED IN THE PATHOGENESIS OF ULTRAFILTRATION FAILURE IN PERITONEAL DIALYSIS PATIENTS?

Anniek Vlijm, Amsterdam, Netherlands

MP298 THE ULTRA-STRUCTURAL HETEROGENEITY OF THE MINERAL PHASE IN HUMAN CALCIFIED ARTERIES

Steven Verberckmoes, Wilrijk, Belgium

MP318 TRADITIONAL (AGE, CARDIOVASCULAR HISTORY) AND NON-TRADITIONAL (HEMATOCRIT, FERRITIN) FACTORS ASSOCIATED WITH AORTIC CALCIFICATION IN PATIENTS WITH STABLE CHRONIC KIDNEY DISEASE STAGE 5D

Kathleen Claes, Leuven, Belgium

MP347 PARICALCITOL AND CALCITRIOL EFFECT ON ATHEROSCLEROSIS AND HEART DISEASE IN UNINEPHRECTOMIZED ApoE -/- MICE

Luis Eduardo Becker, Heidelberg, Germany

MP373 DOES ROUTINE BLOOD SAMPLING CONTRIBUTE TO THE IRON REQUIREMENTS OF RENAL PATIENTS? A COMPARISON OF A HAEMODIALYSIS AND PERITONEAL DIALYSIS POPULATION William Herrington, Reading, UK

MP444 BIOCOMPATIBLE LOW GLUCOSE DEGRADATION PRODUCTS DIALYSIS SOLUTION IMPROVES SURVIVAL IN CAPD PATIENT

Seung Hyeok Han, Seoul, Korea

MP455 URINE PROTEOMICS PROFILING BY MATRIXASSISTED LASER DESORPTION/IONIZATION TIME OF FLIGHT MASS SPECTROMETRY AS A NON-INVASIVE DIAGNOSTIC TOOL IN CHRONIC

ALLOGRAFT DYSFUNCTION

Luis F. Quintana, Barcelona, Spain

MP458 MODULATION OF IMMUNO-PROTEASOME IN CIRCULATING LYMPHOMONOCYTES OF PATIENTS WITH IgA NEPHROPATHY AFTER TRANSPLANTATION

Roberta Camilla, Turin, Italy

MP461 COMPARABILITY BETWEEN THE CMV SEROSTATUS AND THE PRESENCE OF CMV-SPECIFIC T CELLS IN SOLID ORGAN TRANSPLANT CANDIDATES: A CROSSSECTIONAL OBSERVATIONAL CLINICAL STUDY

Amaryllis H. Van Craenenbroeck, Edegem, Belgium 
MP472 SIGNS OF CELLULAR SENESCENCE IN CYCLOSPORINE A AND TACROLIMUS TREATED RENAL TUBULE CELLS Christian Koppelstaetter, Innsbruck, Austria

MP477 DONOR PRE-TREATMENT WITH AN HIFPROLYLHYDROXYLASE-INHIBITOR IMPROVES FUNCTION AND INCREASES LONG-TERM GRAFT SURVIVAL IN AN ALLOGENIC RAT TRANSPLANT MODEL Wanja M. Bernhardt, Erlangen, Germany

MP493 CLINICAL RELEVANCE OF PREFORMED HLA DONORSPECIFIC ANTIBODIES IN KIDNEY TRANSPLANTATION

Carmen Lefaucheur, Paris, France

MP495 PROTEINURIA AND SIROLIMUS: ANALYSIS OF 185 PATIENTS

Rita Birne, Carnaxide, Portugal

MP515 OCCULT HBV INFECTION IN RENAL TRANSPLANT: A STUDY OF PREVALENCE AND INCIDENCE IN TWO TRANSPLANT CENTERS OF NORTHERN ITALY

Roberta Fenoglio, Novara, Italy

TO001 MONITORING OF BKV LOAD IN URINE ALLOWS IDENTIFICATION OF PATIENTS WITH THE HIGH RISK FOR BKV-ASSOCIATED NEPHROPATHY SEVERAL WEEKS PRIOR TO DEVELOPMENT OF VIREMIA: ANALYSIS OF 4128 URINE AND SERUM SAMPLES

Nina Babel, Berlin, Germany

TO002 CIRCULATING ENDOTHELIAL PROGENITOR CELLS AND GRAFT LOSS IN RENAL TRANSPLANT PATIENTS

Maria Jose Soler, Barcelona, Spain

TO005 MYCOPHENOLATE MOFETIL VS. SIROLIMUS IN HIGH IMMUNOLOGIC RISK RENAL TRANSPLANT RECIPIENTS RECEIVING TACROLIMUS-BASED IMMUNOSUPPRESSIVE REGIMEN WITH ATG INDUCTION

Olga Tronina, Warsaw, Poland

TO010 SHORT TELOMERES ARE ASSOCIATED WITH INFLAMMATION, LOW FETUIN-A LEVELS AND MORTALITY IN PREVALENT HEMODIALYSIS PATIENTS

Juan Jesus Carrero, Stockholm, Sweden

TO013 PREDICTING ABNORMAL ALBUMIN EXCRETION RATE BY FIBRINOGEN LEVELS IN TYPE 2 DIABETES MELLITUS PATIENTS

Antonio C. Cordeiro, Sao Paulo, Brazil

TO014 THE ROLE OF PROTEIN KINASE-C-alpha (PKCalpha) IN TGF-beta AND GLUCOSE INDUCED APOPTOSIS IN PODOCYTES

Irini Tossidou, Hannover, Germany

TO019 IMPROVED SURVIVAL OF TYPE 1 DIABETICS IN RENAL REPLACEMENT THERAPY Patrik Finne, Helsinki, Finland

TO020 VARIATION BETWEEN DIALYSIS CENTRE ACHIEVEMENT OF AUDIT MEASURES FOR SERUM PHOSPHATE IN HD PATIENTS. DATA FROM 17,000 PATIENTS IN 55 CENTRES

Alexandra Hodsman, Bristol, UK

\section{Legenda}

Eight Best Abstracts

- Eleven Best Abstracts presented by Young Authors

$\star$ Best Abstracts presented by Young Authors 